\title{
Investment analysis of a new solar Power Plant
}

\author{
Doruk Sen ${ }^{1, *}$, Murat Tunc ${ }^{2}$, Taylan Ozilhan ${ }^{3}$ \\ ${ }^{1}$ School of Management, University of York, York, United Kingdom \\ ${ }^{2}$ Faculty of Engineering, Gedik University, Istanbul, Turkey \\ ${ }^{3}$ Dept. of Industrial and Systems Engineering, Yeditepe University, Istanbul, Turkey
}

\section{Email address:}

ds1010@york.ac.uk (D. Sen)

\section{To cite this article:}

Doruk Sen, Murat Tunc, Taylan Ozilhan. Investment Analysis of a New Solar Power Plant. International Journal of Renewable and Sustainable Energy. Vol. 2, No. 6, 2013, pp. 229-241. doi: 10.11648/j.ijrse.20130206.17

\begin{abstract}
The aim of this study is to propose a guideline for solar energy investment. Two solar energy investment methods are discussed for the investors: Photovoltaic (PV) Power Plants and Parabolic Trough Power Plants (PTPP). In this study, parabolic trough investment is discussed with Molten Salt technology which is one of the most advanced thermal energy storage systems. This technology is crucial for solar investment because it distinguishes these systems from other types of power plants by enabling electricity generation on cloudy days and/or during the night. Investment analysis of both plant types are completed with engineering and economic feasibility studies. This study focuses on solar energy potential of the city of Konya, Turkey and 10 MW installed capacity is applied for 25 years in both plant types as a case study. Comparison of obtained results is heavily based on net present value (NPV) approach. Empirical results demonstrate that the proposed methods are viable approaches for solar investment in Konya. On the other hand, it generates a guideline for investors in other countries by applying the solar insolation variables of the location to thermodynamic equations which are proposed in this article. However, the investment strategy varies depending on the solar potential and decision maker's risk attitude.
\end{abstract}

Keywords: Photovoltaic, Parabolic Trough, Molten Salt, Energy Storage, Investment

\section{Background and Introduction}

Solar energy is widely used in Turkey. The purpose of using solar energy is mainly based on heating and drying agricultural products. Other big scale applications of solar energy are used especially in developed countries. Until the mid-70s, there was no significant usage of solar energy in Turkey. Parallel to the technology development, some of the universities started their solar energy applications. The term "solar energy industry" was first mentioned during those years. Technical studies are encouraged in universities and investments made at 60 s started to yield their results by increasing interest. After mid-70s, solar energy applications started to increase rapidly. First national congress about solar energy was held in Izmir in 1975. At the same year, Middle East Technical University (METU) held first inactive solar application. Interest on solar energy encouraged other universities in Turkey for research on solar energy including Istanbul Technical University (ITU), Yildiz Technical University (YTU), and Ege University. Solar energy institute in Turkey is in Ege University, which is located in Izmir. The institute has established in 1978. By the end of $80 \mathrm{~s}$, most of the applications have been done by The Scientific Technological Research Council of Turkey (TUBITAK). Classification of solar energy applications in Turkey divided into two groups for detailed investigation. They are; 1. Low Temperature Applications: The most important and industrially successful applications of low temperature applications are hot water systems. It has a widespread usage in Turkey. Water boilers using solar radiation have firstly been produced in Izmir during 1975. After its recognition, different companies which are in the industry started to manufacture and sell it. 2. High Temperature Applications: Industrial usage of high temperature applications can be investigated on steam generation history of the country. The first steam generation by solar energy in the industry was achieved in 1986. After its initial success, active solar energy studies were commenced by Turkey branch of Industrial Solar Energy by the permission of Turkish government. In addition to this, Makine ve Kimya Endustrisi Kurumu (MKEK) has worked on plat mirrors for short amount of time. Necessity of investing in solar energy is increasing each day. With 
average total annual sunshine duration is estimated as 2640 hours, daily total average is 7.2 hours, average total solar radiation $1311 \mathrm{kWh} / \mathrm{m}^{2} a$ (kilowatt-hour per metre-square annum), and daily total of $3.6 \mathrm{kWh} / \mathrm{m}^{2}$, Turkey has a better sunshine duration when it is compared to the most of the countries in Europe. In addition to this, high energy potential of the country (approximately 110 days per year), should enable the investment to reach higher outcomes. According to the latest researches, some of the European countries have considerable incentives for the investors. Similar approach is applied by Turkish government recently. Incentives include 10 year fixed price applied for PV and CSP (Concentrated Solar Power) plants which start their electricity generation before 31.12.2015. This fixed price is determined by cabinet decree as 13.3 USDcent/ kWh (United States Dollar cent per kilowatt-hour). Date of 31.12.2015 could be extended by the same authority. This regulation also supports domestic production of components used in solar energy plants. Additional incentives (listed in Table 1.) are going to be applied for domestic PV and CSP products until the end of year 2015.

Table 1. Additional Incentives

\begin{tabular}{|c|c|c|c|}
\hline $\begin{array}{c}\text { Component of } \\
\text { PV }\end{array}$ & $\begin{array}{c}\text { Additional } \\
\text { Incentive } \\
\text { (USDcent/ kWh) } \\
\end{array}$ & $\begin{array}{l}\text { Component of } \\
\text { CSP }\end{array}$ & $\begin{array}{c}\text { Additional } \\
\text { Incentive } \\
\text { (USDcent/ kWh) }\end{array}$ \\
\hline Panel Integration & 0.8 & Vacuumed tube & 2.4 \\
\hline Modules & 1.3 & Reflective Surface & 0.6 \\
\hline Solar Cells & 3.5 & $\begin{array}{l}\text { Sun-Tracking } \\
\text { System }\end{array}$ & 0.6 \\
\hline Inverter & 0.6 & Heat Storage & 1.3 \\
\hline \multirow[t]{2}{*}{ Radiation Focuser } & 0.5 & Stirling Engine & 1.3 \\
\hline & & Panel Integration & 0.6 \\
\hline
\end{tabular}

The rest of this article is organized as follows: The investment analysis framework is presented in Section 2. The next section illustrates construction site, PV plants investment analysis and parabolic trough investment analysis within the headline of investment analysis. Section 4 includes results and discussion. Computational results are also discussed in this article which is detailed in Appendix A\& B.

\section{Investment Analysis Framework}

Investment analysis in this research is the combination of engineering and economic studies. Engineering studies applied on panel selection in PV modules, and on thermodynamic calculations of parabolic trough plant to estimate its expected electricity generation. On the other hand, economic studies are heavily involved with their cost and projected revenue estimations. This part includes expected worth of the project by implementing powerful tools such as Return on Investment (ROI), Minimum Attractive Rate of Return (MARR) and Net Present Value (NPV). The main objective of this article as mentioned above is to elaborate possible strategies of investing in solar energy. Evaluation procedure in this purpose consists of three main steps as summarized below.

Step 1. Identifying Construction Site

Step 2. Photovoltaic Power Plant Investment Analysis

Step 3. Parabolic Trough Investment Analysis

The detailed descriptions of each step are illustrated in the following sections and all monetary calculations are in United States Dollar (USD).

\section{Investment Analysis}

\subsection{Selection of Construction Site}

Selection of the construction site is the first important topic for investment analysis. Thus, chemical, and physical properties of the land plays an important role in selection of location. Site selection process can be investigated by following criteria;

- Solar Resource: Global horizontal irradiation, inter-annual variation of resource, and shading impact

- Local Climate: Flooding, high winds, snow, and extreme temperatures

- Available Area: Module technologies, Access requirement, and inter-row shading of modules

- Land Use: Land cost, environmental sensitivity, and impact of other land users

- Topography: Flat or slightly south facing slopes in the northern hemisphere

- Geotechnical: Groundwater, resistivity, soil $\mathrm{pH}$ levels, and seismic risk

- Geopolitical: Sensitive military zones should be avoided

- Accessibility: Proximity to existing roads, and road extension

- Grid Connection: Cost, timescales, capacity, proximity, and availability

- Module Soiling: Local weather factors, environmental \& human factors, and wildlife factors

- Water Availability: Reliable water supply needed for module cleaning

- $\quad$ Financial Incentives: Feed-in-tariffs [1]

After serious consideration about steps mentioned above and capacity availability of transformer stations, Konya seemed feasible location to generate electricity by using PV modules. Solar potential of the city could be briefly explained by 7.2 hours of sunshine duration and global horizontal radiation of $1700 \mathrm{kWh} / \mathrm{m}^{2}$ on yearly average. Thus, all of the calculations are made on yearly basis. Konya is largest city in Turkey in terms of $\mathrm{km}^{2}$. Most of its area is flat croplands. Having flat croplands is a wonderful opportunity for site selection steps such as; available area, land use, topography.

In order to discuss other steps including accessibility, grid connection, geopolitical, and finance, construction site 
should be selected. Since there are government incentives in renewable energy, energy investment incentive land could be found in order to make the licensing easier and minimizing the land cost. To do this, investment incentive areas which belong to the state and ready for auction are searched. One of the good alternatives is located in Eregli, Konya. The land has $594205 \mathrm{~m}^{2}$. [2] Site with this scale, enables the expected installed capacity of power plants represented with MW. Cost of the land is assumed as USD 247585 which is the initial price of the auction. Another important topic to discuss is its proximity to the transformer station. Farther the station is, more loss generation of the electricity. Although the location seems feasible in most of the criteria, it is $20 \mathrm{~km}$ (kilometers) away from the transformer station. Closest transformer station to the area is Eregli transformer station which is in Konya-2 region. In terms of degree, minute and second transformer station is located on $37^{\circ} 32^{\prime} 23.167^{\prime \prime} \mathrm{N}$ latitude and $34^{\circ} 5^{\prime} 14.523^{\prime \prime} \mathrm{E}$ longitude. It is estimated that $20 \mathrm{~km}$ distance can generate $6 \%$ loss of the electricity generated. Detailed discussion of the distance- electricity generation is shown in further steps. However, in order to reduce the loss, investors may negotiate with local landlords who have closer properties to the transformer station.

\subsection{Photovoltaic Power Plant Investment Analysis}

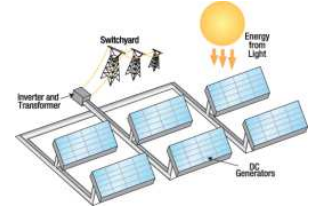

Figure 1. [3]

A photovoltaic power plant consists of 5 main elements (shown in Figure 1). They are;

- Photovoltaic Panel

- DC Cable

- Inverter

- Transformer

- $\quad$ String Monitor

Photovoltaic panels are formed by photovoltaic cells and other components. The main component can be considered as photovoltaic cells. By using these cells, photovoltaic panels transforms solar energy directly to electricity. There are plenty of photovoltaic panels with different outputs. As it is shown in figure 1, panels are connected either serial or parallel to have large amount of installed capacity. These systems are all electronic and since there are no moving parts, it has very long useful life such as 30-40 years. However, according to many studies, and industrial perspective, it is indicated that efficient useful life of photovoltaic panels are 25 years. We have investigated our further studies based on 25 years of useful life. Although solar cells are mainly formed by silicon material, they are not enough to generate expected electricity. Since there is no rankine cycle in the system for electricity generation, materials formed by boron and phosphorus are added to the silicon material. By doing this, + and - poles are obtained in the system. In other words, electric current is transferred through the material. Voltage obtained in the panels is direct current. Thus, it is not possible to use it at home or industrial facilities. Direct Current (DC) is needed to be converted to Alternative Current (AC) in order to use it. To do this, inverters must exist in the system. If the system is not in large utility scale, small inverters can be added next to several serially connected PV modules. On the other hand, in the larger utility scale projects, central inverters must be added to the system (Figure 1.). Otherwise, there would be reduction of efficiency therefore, increase in cost. Transferred low AC voltage, is sent to transformer to obtain higher voltages of AC current. Finally, it is connected to the closest transformer station by power lines. While the system is generating electricity, whole process should be monitored by string monitors to visualize the total amount of loss and generated electricity.

\subsubsection{Empirical Illustrations for PV Power Plant}

So far, strategies of location selection and electricity generation of PV modules are discussed. Since their price shows huge variability, selecting the right panel is very important for the project. The term 'right' is not only the discussion of less cost and high efficiency, but also the compatibility to other system elements. Similarly, in many real-world cases, there is no single objective exists to maximize or minimize in panel selection process. Brand name, reliability, output power, positive and negative tolerance levels, efficiency, dimensions of the module and many others. These are some of the attributes that could be faced in order to minimize the cost and maximize the output.

First of all, installed capacity of the plant should be determined. Number of panels required, shows difference with respect to the size of the plant in terms of capacity. In this case, 10 Mega-Watt (MW) installed capacity is determined to generate electricity. Generated electricity and total cost of the panels can be calculated according to the following steps by using the information obtained about the panel characteristics;

Step1. Calculation of number of panels and solar field required

It is required to obtain the installed capacity of $10 \mathrm{MW}$. To do this, unit conversion should be made. Afterwards, necessary calculation to find the 'total number of panels required' is completed by dividing that amount to the module output in terms of Watt (W). For instance, considering that the system runs with a module of $245 \mathrm{~W}$ (which is alphabetically first brand and module amongst other brands in Appendix A, Brand: Astro Energy, Model: CHSM 6610P-245 discussed further in Appendix A, Step 1), 40817 modules required by the equation (1) below.

$$
10 \times 10^{6} \mathrm{~W} / 245 \mathrm{~W}=40816.326 \sim 40817 \text { modules }
$$

Assuming that the surface area (in square meter) of the 
module is $1.642 \mathrm{~m}^{2}$ (Astro Energy, CHSM 6610P-245, Appendix A), multiplication of total number of modules required with the unit surface area yields the total solar field in equation (2).

$$
1.642 \mathrm{~m}^{2} \times 40817=67021.51 \mathrm{~m}^{2}
$$

Step2. Total panel cost estimation

Total cost of the photovoltaic modules is calculated by the multiplication of the unit cost of the model with the total number of modules required. Since, previous two calculations are based on Astro Energy CHSM 6610P-245, further symbolic calculations of PV modules are discussed based on that. Price of the unit module discussed as United States Dollar (\$) 258 (Appendix A, Step 2). Thus, equation (3) yields the total panel cost.

$$
\$ 258 \times 40817=\$ 10530786
$$

Step3. Calculation of positive and negative tolerance levels of the photovoltaic module

In this step, positive and negative tolerance levels (obtained from the model instructions) are added and subtracted from the installed capacity of the module. For instance, if the system runs with a photovoltaic module of 245 Watt with $+3 \%$ and $-0 \%$ positive and negative tolerance percentages, its relative levels becomes 252.35 Watt and 245 Watt respectively. It is discussed in step 3 of Appendix A.

Step4. Estimated yearly electricity generation

The city of Konya has 7.2 hours of sunshine duration per day and it is assumed that the plant generates electricity throughout the year without any interruption. To find the total Mega-watt-hour (MWh) per year with negative tolerance level; values of average sunshine duration, days that the system operates per year, negative tolerance level and number of modules required are multiplied in terms of MW as equation (4).

$$
\begin{gathered}
(7.2 \mathrm{~h} / \text { day } \times 365 \text { day } / \text { year } \times 245 W \times 40817) \\
/(1000000 W / M W)
\end{gathered}
$$

$$
=26280.43362 M W h / \text { year }
$$

Same approach is applied to obtain total MWh per year with positive tolerance level by replacing $245 \mathrm{~W}$ with 252.35 W (Astro Energy CHSM 6610P-245) in the equation above. By taking the average of positive and negative tolerance levels; yearly MWh productions, average MWh per year can be calculated. This new average MWh is considered as plant's annual production. In this case, it is calculated as 26674.64012 MWh/year. It is shown detailed with different brand name and modules in step 4 of Appendix A. Moreover, module efficiency has a great role in generated electricity. Thus, efficiencies of the modules should be investigated. Most of the modules assumed to have linear reduction in their efficiencies over years. According to the common view, solar plants which are formed by photovoltaic modules have a useful life of 25 years. By supporting the idea, module efficiencies are calculated and average efficiency rate for 25 years per module is found. In this example, it is taken as $80 \%$.

Step 5. DC cable connection

Each PV module needs to be connected to inverters by DC cables (transfers obtained DC to the inverters) and on average they are considered as 10 meters away from the closest inverter. Practically, 2000 modules could be connected to each industrial inverter (discussed on step 6), and connection cable has efficiency rate $99 \%$. The information for the necessary cable for DC illustrated below;

Brand/ Model/ Price : Top Cable/ PV ZZ-F(AS)/ \$1508 per meter [4][5]

Step 6. Inverter integration

As it is discussed in previous sections, inverters are important parts of the system. One of the leading inverter manufacturers especially in Europe is SMA inverters. Number of inverters required in the system depends on the inverter type. Since the project is in utility scale, central inverters should be used. Based on previous discussions and the information gathered from suppliers, optimal inverter is found and one central inverter is needed for every 2000 photovoltaic modules. Number of inverters required and total inverter cost are found as equations $(5,6)$. The inverter found has $92 \%$ efficiency and other information listed below;

- $\quad$ SMA Sunny Central SC 500CP-XT

- $\quad$ Price: \$ 93806.102 [6]

$$
\begin{aligned}
& \frac{40817 \text { modules }}{2000 \text { modules } / \text { inverter }} \\
& =20.4085 \sim 21 \text { inverters }
\end{aligned}
$$

21 inverters $\times 93806.102 \$ /$ inverter $=\$ 1969928$

Step7. Transformer and local network connection

Transformers are used in systems to convert low voltage to high voltage for making connection to the network. Transformer used in the systems is discussed below as;

Brand/ Price/ Efficiency: SMA Sunny Central TSC 500SC-DE/ \$28929.8/ 99\% [7]

Once high voltage electricity is obtained by transformer in the system, it needs to be connected to the local network by transformer station. Nearest transformer station to the construction site is $20 \mathrm{~km}$ away. Loss generated by this distance is found as $6 \%$. The associated cost is shown in equation (7).

$$
55.55 \$ / m \times 20000 m=\$ 1111000
$$

Step8. String monitor integration

String monitors are needed to monitor the generated electricity as well as loss. 24 modules require one string monitor. It has a cost of \$3203.2[8] Total number of string monitor and relative cost is calculated in equations (8), (9). 


\author{
(40817 module)/(24 module / monitor) \\ $=1700.7 \sim 1701$ monitors
}

$$
1701 \text { monitor } \times 3203.2 \$ / \text { monitor }=\$ 5448643
$$

Calculations above are completed by information of Astro Energy CHSM 6610P-245. However, detailed information of steps $5,6,7$, and 8 are discussed in figure 5 of appendix A.

Step9. Efficiency parameters, efficiency applied electricity generation and confidence level

So far lots of efficiency parameters are discussed. They could be classified as; 25 years module efficiency, DC cable efficiency, inverter efficiency, transformer efficiency, power line efficiency. For Astro Energy CHSM 6610P-245, they are $0.8,0.99,0.92,0.99$, and 0.94 respectively. Since there are so many parameters, finding one coefficient for all, simplifies calculations. Multiplication of efficiencies discussed above yields 0.678. Afterwards, efficiency coefficient should be multiplied with the average electricity generation found in previous sections as equation (10).

$$
\begin{aligned}
& 26674.64012 \mathrm{MWh} / \text { year } \times 0.678 \\
= & 18087.337 \mathrm{MWh} / \text { year }
\end{aligned}
$$

However, average electricity generation found in equation (10) is highly deterministic. To eliminate deterministic approach and convert it to a more stochastic environment, confidence level should be applied to some extent. Since, PV systems are highly reliable, it would be fair to choose $90 \%$ confidence level before commencing on economic studies. Multiplying the result obtained in equation (10) with 0.9 confidence level yields $16278.603 \mathrm{MWh} /$ year. Different brands and modules are calculated by using same approach and shown in appendix A (figure 6).

Step10. Expected annual sales revenue and Net Present Value approach

According to the regulations, standard conditions state that the system may sell each MWh for $\$ 130$. Thus, expected annual sales revenue is calculated by multiplying the new value found in the previous equation by $\$ 130$. $\$ 2116218.408$ is calculated as expected annual sales revenue.

There are several methods to discuss the alternatives whether they are feasible or not. One of the good methods is to separate alternatives is, net present value approach. In this approach, each alternative is considered as a project. One of the most important ideas in this approach is the time value of money. Money has a value today. However, today's $\$ 100$ is no longer $\$ 100$ next year. There are many affects that determines the new value of money in the further years. That is discussed in NPV technique by discounting all cash inflows and outflows to the base point or beginning point with an interest rate which is the Minimum Attractive Rate of Return (MARR). In this study, perspective of the opportunity cost was employed in the decision of Minimum Acceptable Rate of Return of $3.75 \%$, which is the present bank saving account interest rate on USD in Turkey. Even though it is necessary to be able to calculate the MARR by covering interest foregone, inflation, and risk premium, only the interest rate is taken into account to suggest more practical results. The idea is to calculate today's value of all cash flows in further years. The alternative which yields the highest NPV, should be selected. Similar to the previous discussions, different brands and their models are discussed and resulted in Appendix A. [9]

\subsection{Parabolic Trough Power Plant Investment Analysis}

Parabolic trough power plants (PTPP) are the most common and developed concentrating solar thermal plants with present technology. This technology is still proving itself as commercially and academically. The PTPP contains a solar area (Left hand side of the Figure 2.) filled with hundreds or thousands of solar collector assemblies (SCA) depending on the size of the project. This area also named as solar field in different research methods. The SCA's consist of four subsystems and each of them has a crucial importance for this system. These are concentrator structure, reflectors, heat collection element and collector balance of system. Moreover, in this plant, the heat transfer fluid circulates through the heat collection element. It is used to transport the energy through each part of the system.

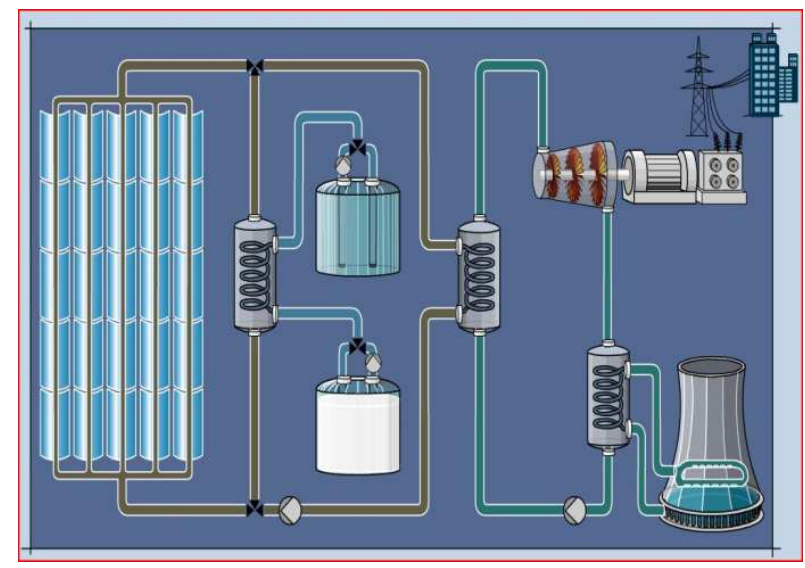

Figure 2. Schematic of PTPP with Two Tank Molten Salt System [10]

The system starts working by the hit of solar radiation to reflector of the parabolic trough. Reflectors are used to reflect the incoming radiation to the linear receiver tube. As it is shown in figure 2, this tube is placed inside of the trough (left hand side of figure 2) and it is also called as the heat collection element of the system. The heat transfer fluid is placed inside of the linear receiver tube. The fluid is heated by the reflected radiation. Furthermore, it flows to the second (from left to right) heat exchanger in figure 2 which transfers the energy of heated fluid to the liquid water. Thus, it heats the liquid water until it reaches the steam phase. The steam flows to the steam turbine which is on right top of figure 2 and it generates electricity. In the further steps of the system, the steam also flows to the condenser, which 
converts steam to water (discussed in right below) by third heat exchanger in the figure above. The system description which is mentioned above can be named as a parabolic trough power plant without energy storage. As a second discussion of this system, it has been witnessed that energy storage by a molten salt technology is used in parabolic trough power plants. To support the idea, two tank molten salt systems which are composed of hot and cold tank are discussed in the rest of this research (Middle part of figure 2.). When the solar radiation is more than the necessity of the system, the molten salt which rests in the cold tank is heated via first heat exchanger in the figure 2 and pumped to the hot salt tank. The molten salt which rests in the hot tank is transferred to the cold tank and it transfers the energy to the heat transfer fluid by heat exchanger. This system is used when the solar radiation is not enough to run the turbine with expected efficiency, and/ or during the night. Then, the system continues with the same process discussed previously.

\subsubsection{Empirical Illustrations for Parabolic Trough Power Plant}

Prior to the cost estimations for the investment analysis, heat transfer and thermodynamic calculations should be completed. Following calculations are discussed for the parabolic trough solar power plant without thermal storage. Numerical values of total aperture area, total number of collectors required, and the total mass of heat transfer fluid required which circulates in the system. In addition to this, total mass of molten salt is significantly important if there is an energy storage system exists in the parabolic trough solar power plant. In this example, the heat transfer fluid (oil) which circulates in the system is assumed as Therminol VP-1. Therminol VP-1 is selected for the system because operational temperature range and the stability of the oil are more appropriate than the other heat transfer fluids for the discussions of the power plant. The molten salt technology used in the system is assumed as Solar Salt for further calculations. Solar Salt has low storage cost and sales price. Thus, it is ideal for PTPP systems. Luz-3 collector (solar field in figure 2) is assumed to be used in the power plant as a parabolic trough in the power plant. The location and solar radiation data which is discussed in PV investment is taken into account for PTPP investment in accordance of homogeneity. Steam turbine (right-top of figure 2) which is discussed in the system operates at $500{ }^{\circ} \mathrm{C}$ (degrees in Celsius) and $11 \mathrm{MPa}$ (Mega-Pascal).

Step1. Thermodynamic calculations

As it is indicated on figure 3, rankine cycle is the fundamental operating cycle of all power plants where an operating fluid is continuously evaporated and condensed. Thus, it is used to generate electricity in the parabolic trough power plant.[14] The useful steam turbine energy for the rankine is found with the equality of enthalpy values. In this analysis, the entropy of the steam turbine $\left(s_{-} 3\right)$ assumed to be equal to the entropy of the condenser $\left(s_{-} 4\right)$. Entropy has a unit of $\mathrm{kJ} / \mathrm{kg}^{\circ} \mathrm{K}$. (kilojoule/kilogram-kelvin)

$$
s_{-} 3=s_{-} 4=6.54268 \mathrm{~kJ} / \mathrm{kg}^{\circ} \mathrm{K}
$$

Dryness fraction of steam $\left(x_{-} 4\right)$ is discussed in many research topics as the quantity of saturated vapor in unit mass of wet vapor, which is also referred as the dryness fraction, or quality of the vapor. Quality of the vapor is indicated in the Mollier diagram in figure 4. The diagram discusses the dryness fraction of steam which can be in between $0-1$, in different enthalpy and entropy levels. As the wetness of steam increases, the quality of it increases accordingly. Thus, it is derived to calculate the enthalpy of the condenser $\left(h_{-} 4\right)$, which is defined by the addition of the internal energy with the multiplication of pressure and volume.[15] Thermodynamic properties of steam are used in the following equations (12) and (13).

$$
\begin{aligned}
x_{-} 4 & =\left(s_{-} 4-s_{-} f\right) / s_{-} f g \\
& =((6.54268-0.8931)) / 6.9383 \\
& =0.81426 \\
h_{-} 4 & =h_{-} f+x_{-} 4 \times h_{-} f g \\
& =271.93+0.81426 \times 2346.3 \\
& =2182.4282 \mathrm{~kJ} / \mathrm{kg}
\end{aligned}
$$

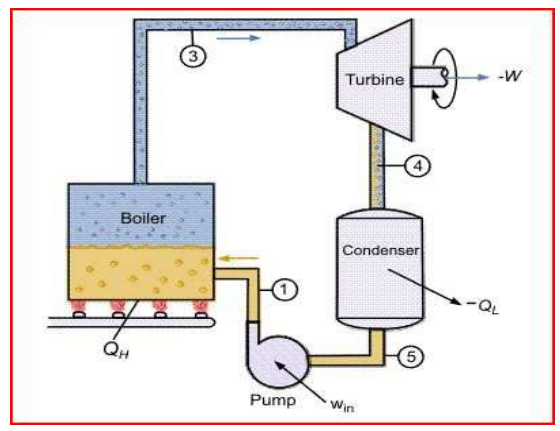

Figure 3. Rankine Cycle [14]

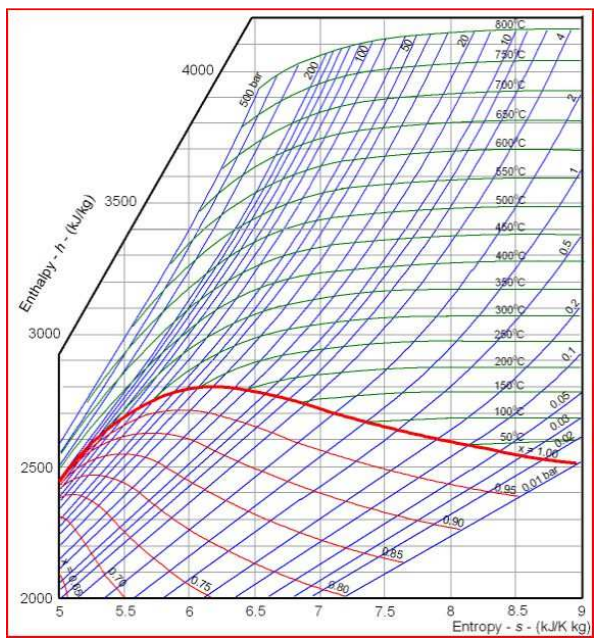

Figure 4. Mollier Diagram [16]

Step2. Mass flow rate calculations

The useful turbine energy $\left(W_{-} T\right)$ is calculated with the 
equation (14) and the efficiency of the turbine $\left(\mu_{-} T\right)$ assumed to be equal to $38 \%$. Furthermore, to reach the value of enthalpy of steam turbine ( $\left.h \_3\right), 11 M P a$ value is found with an interpolation between $10 \mathrm{MPa}$ and $12.5 \mathrm{MPa}$. The interpolation yields to $3360.94 \mathrm{~kJ} / \mathrm{kg}$ at $500^{\circ} \mathrm{C}$.

$$
\begin{aligned}
W_{-} T= & \mu_{-} T \times\left(h_{-} 3-h_{-} 4\right) 0.38 \times(3360.94- \\
& 2182.4282)=447.8345 \mathrm{~kJ} / \mathrm{kg}
\end{aligned}
$$

The turbine outcome energy is taken into account as $10 \mathrm{MW}(10000 \mathrm{~W})$. Thus, the mass flow rate of the water ( $\left.m_{-}\left(H_{-} 2 O\right)\right)$ is calculated as;

$$
\begin{array}{r}
m_{-}\left(H_{-} 2 O\right)=\mathcal{W}_{-} T / W_{-} T=10000 / 447.8345= \\
22.3297 \mathrm{~kg} / \mathrm{s}
\end{array}
$$

In addition to this, the equality discussed below considered as the mass flow rate of the oil $\left(m_{-}^{*} o i l\right)$ which flows through the system. Enthalpy of water passing through collectors $\left(h \_2\right)$ is found from the thermodynamic properties of steam table after another interpolation between $10 \mathrm{MPa}$ and $12.5 \mathrm{MPa}$ valued at $60^{\circ} \mathrm{C}$. The specific heat of Therminol Vp-1 (Cp_oil) is given as $2.39 \mathrm{~kJ} / \mathrm{kg}^{\circ} \mathrm{K}$ and during the operation, temperature difference of oil is indicated as $\Delta T_{-}$oil.

$$
m_{-} \text {oil }=\left(m_{\times}^{\cdot}(H 2 O) \times\left(h \_3-h \_2\right)\right) / /\left(C p_{-} o i l\right)
$$$$
(22.3297 \times(3360.94-260.326)) /(2.39 \times 245)=
$$$$
118.24 \mathrm{~kg} / \mathrm{s}
$$

Step3. The heat transfer coefficients calculations

Two heat transfer coefficients are calculated for the system. The first type is the convective heat transfer coefficient which is in between receiver and fluid, and the second type is the radiation heat transfer coefficient. Radiation heat transfer coefficient is in between absorber tube and ambient. These values increase the reliability and authenticity of the investment analysis.

Step 3.1. The convective heat transfer coefficient between receiver and fluid

$$
\begin{array}{r}
h \_2=h_{-}(c, i)=k_{-} w /\left(D_{-}(r, \text { int })[3.6+(0.0668 \times\right. \\
\left.\left(D_{-}(r, \text { int }) / L_{-} \text {collector }\right) \times R e_{-} w \times P r_{-} w\right) /(1+ \\
0.04\left[\left(D_{-}(r, \text { int }) / L_{-} \text {collector }\right) \times R e_{-} w \times P r_{-} w\right]^{\wedge}(2 /
\end{array}
$$$$
\text { 3) )])) }
$$

The Reynolds number of water is written as;

$$
R e_{-} w=\left(u_{-} w \times D_{-}(r, i n t)\right) / v_{-} w
$$

The water velocity is discussed with the following equation;

$$
u \_w=M /\left(\rho \_w \times A_{-}(c, r, i n t)\right)
$$

The cross sectional area of receiver due to internal diameter is calculated as;

$$
A_{-}(c, r, i n t)=\left(\pi \times D_{-}(r, i n t)^{\wedge} 2\right) / 4
$$

[11]

The convective heat transfer coefficient between receiver and fluid is $40.550 \mathrm{~W} /\left(\mathrm{m}^{2}{ }^{\circ} \mathrm{C}\right)$ and this value is found with the following Matlab $\mathrm{m}$-file codes

$\mathrm{kw}=0.124 ; \quad \%$ Conductivity of Therminol VP-1 $(\mathrm{W} /(\mathrm{m} * \mathrm{C})) \%$

Drint $=0.0606$; \% Internal Diameter of Receiver (m) \% $\mathrm{L}=99 ; \%$ Length of Collector $(\mathrm{m}) \%$

Prw $=0.714 ; \%$ Prandtl Number $\%$

$\mathrm{vw}=0.000000726$; \% Kinematic Viscosity of Therminol VP-1 ( $\mathrm{m}^{\wedge} 2 /$ second $) \%$

$\mathrm{M}=118.24$; \% Mass Flow Rate $(\mathrm{kg} / \mathrm{sec}) \%$

pw=974; \%Density of Therminol VP-1 $\left(\mathrm{kg} / \mathrm{m}^{\wedge} 3\right) \%$

Acrint $=\left(\right.$ pi $\left.^{*}(\text { Drint })^{\wedge} 2\right) / 4$;

$\mathrm{uw}=\mathrm{M} /\left(\mathrm{pw}^{*}\right.$ Acrint $)$;

Rew $=\left(u^{*}\right.$ Drint $) / v w$;

hci $=(\mathrm{kw} /$ Drint $) *(3.6+((0.0668 *($ Drint $/ \mathrm{L}) *$ Rew $*$ Prw $) /(1+$

$\left.\left.\left.0.04 *\left((\text { Drint } / \mathrm{L}) * \operatorname{Rew}^{*} \operatorname{Prw}\right)^{\wedge}(2 / 3)\right)\right)\right)$;

hci $=40.550$

Step3.2. The radiation heat transfer coefficient between absorber tube and ambient

Ambient temperature $\left(T_{-} a m b\right)$ of Konya is $18{ }^{\circ} \mathrm{C}$ or $291{ }^{\circ} K$. The radiation heat transfer coefficient between absorber tube and ambient $\left(h \_1\right)$ is calculated with the following formula. Emissivity $(\varepsilon)$ of receiver equals to 0.9 , which is constant. Furthermore, $\sigma$ equals to $5.66 \times 10^{-8}$ which is Stefan-Boltzmann constant. In this case, temperature of receiver $\left(T_{-} r\right)$ is taken approximately as $430{ }^{\circ} \mathrm{C}$ or $705^{\circ} \mathrm{K}$.

$$
\begin{array}{r}
h \_1=h_{-}(r, r-a)=\varepsilon \times \sigma \times\left(T_{-} r+T_{-} a m b\right) \times\left(T_{-} r^{2}+\right. \\
\left.T_{\_} a m b^{2}\right)=29.375 \mathrm{~W} / \mathrm{m}^{2}{ }^{\circ} \mathrm{C}
\end{array}
$$

Step 4. The operational temperature of receiver

$T_{-}$fluid is the operational temperature of Therminol VP-1. It is $135{ }^{\circ} C . T_{-} p$ is the temperature of the collector which is obtained with the equations (22), (23) and (24). Value of $I$ is named as solar radiation and it is equal to $27060 \mathrm{~W} / \mathrm{m}^{2}$. The value of 27060 is obtained by the multiplication of Luz-3 concentration ratio which is 82 and direct solar radiation of Konya. The total solar radiation of Konya is $660 \mathrm{~W} / \mathrm{m}^{2}$. It assumed that 50 percent of it is direct radiation. This new value is used in the further calculations of the parabolic trough power plant.

$$
\begin{gathered}
I=h \_1 \times\left(T_{\_} p-T_{-} a m b\right)+h_{-} 2 \times\left(T_{-} p-T_{-} \text {fluid }\right) \\
27060=29.735\left(T \_p-18\right)+40.555\left(T_{-} p-135\right) \\
T_{-} p=470.4795^{\circ} \mathrm{C}
\end{gathered}
$$

Step5. Calculation of number of collectors and required aperture area

It is required to obtain an installed capacity of $10 \mathrm{MW}$. To do this, unit conversion should be made. It is then necessary to find total number of collectors required by dividing this amount to the module output in terms of $\mathrm{W}$ (Watts). The length of the entire system (L) is given by equation (25). Heat capacity of Therminol VP-1 
is $1858 \mathrm{~kJ} / \mathrm{kg}^{\circ} \mathrm{K}$ for following degree specifications. The diameter of the collector $\left(D_{-}(r, e x t)\right)$ is $0.07 \mathrm{~m}$. The inlet temperature $\left(T_{-} i\right)$ and the exit temperature are $\left(T_{-} e\right)$ orderly $12{ }^{\circ} \mathrm{C}$ and $257.2{ }^{\circ} \mathrm{C}$.

$$
\begin{array}{r}
m_{-} \text {oil } \times C p_{-} o i l \times \Delta T_{-} \text {oil }=h_{-} 2 \times\left(\pi \times D_{-}(r, e x t) \times\right. \\
L)\left(T_{-} p-\left(T_{-} i+T_{-} e\right) / 2\right) \quad(25) \\
118.24 \times 1858 \times 245.2=40.555 \times(3.14 \times 0.07 \times \\
L) \times(470.4795-(12+257.2) / 2) \quad(26) \\
L=17934.69928 \mathrm{~m}=17.934 \mathrm{~km} \quad(27)
\end{array}
$$

The number of collectors needed in the plant is calculated with the equations (28) and (29). To calculate this, the length of a collector is given as $99 \mathrm{~m}$.

$$
\text { \# of collectors }=L / L_{-} \text {collector }
$$

$17934.69928 / 99=181.1585 \cong 182$ Collectors

The aperture area $\left(A_{-} a p\right)$ is calculated as;

$$
\begin{aligned}
A_{-} a p & =\left(W-D_{-}(r, \text { ext })\right) \times L_{-} \text {collector } \\
& =(5.7-0.07) \times 99=557.37 \mathrm{~m}^{2}
\end{aligned}
$$

[11]

The total aperture area is found by;

Total aperture area $=\#$ of collectors $\times A_{-}$ap $=$ $182 \times 557.37=101441.34 \mathrm{~m}^{2}$

The results obtained in Step 5, is indicated in figure 11 in Appendix B. Since this calculation does not include thermal energy storage (molten salt), it is represented as 0 hour molten salt in the figure.

Step6. The total mass of heat transfer fluid (oil)

The total mass of oil which circulates in the system is found by the following equation. There is a positive tolerance which equals to its 11 percent of the total is 1982

$$
\begin{array}{r}
m_{-} \text {oil }=\left(\pi . D_{-}(r, \text { ext })\right) / 4 \times(\# \text { of total collectors } \times \\
\text { L_collector }+ \text { tolerance }) \times \rho_{-} \text {oil } \\
m_{-} \text {oil }=(32) \\
74967.82548 \mathrm{~kg}=74.967 \text { tons }
\end{array}
$$

So far, the system operates without thermal storage as it is discussed between Steps 1-6. All representations of $0 \mathrm{~h}$ molten salt on Appendix B belong to the calculations of steps 1-6. In addition to this, one hour molten salt storage system variables are discussed in further steps as a guide for calculations of 3,6, and 9 hours.

Step7. Mass flow rates of molten salt and oil for one hour thermal storage

The molten salt used in this system is solar salt. Following equality gives the mass flow rate of the molten salt in the system. Heat capacity and temperature range of solar salt, are orderly $1460 \mathrm{~kJ} / \mathrm{kg}^{\circ} \mathrm{K}$ and $200{ }^{\circ} \mathrm{C}$. Heat capacity and temperature range of water equals to $4186 \mathrm{~kJ} / \mathrm{kgK}$ and $440{ }^{\circ} \mathrm{C}$ respectively.

$$
\begin{gathered}
m_{-} \text {oil } \times C p_{-} \text {oil } \times \Delta T_{-} \text {oil }=m_{-}{ }^{\prime} m s \times C p_{-} m s \times \Delta T_{-} m s+ \\
m_{-}(H 2 O) \times C p_{-}(H 2 O) \times \Delta T_{-}(H 2 O) \\
118.24 \times 1858 \times 245.2=m_{-}{ }^{\circ} m s \times 1460 \times 200+ \\
22.3297 \times 4186 \times 440 \\
m_{-}^{*} m s=43.63 \mathrm{~kg} / \mathrm{s}
\end{gathered}
$$

The formula discussed in equation (37) gives the mass flow rate of the oil $\left(\mathrm{m}_{-}\right.$ooil' $)$which circulates in the system only with the energy obtained from the molten salt. Therefore, it is used in calculations in order to find the additional need of collectors to obtain this energy for storage while generating the same amount of steam in further steps.

$$
\begin{aligned}
& m_{-}{ }^{\circ} o i l^{\prime} \times C p \_o i l \times \Delta T \_o i l=m_{-}{ }^{\prime} m s \times C p \_m s \times \\
& \Delta T \_m s(37)
\end{aligned}
$$

$$
\begin{gathered}
m_{-}{ }^{o i l} l^{\prime} \times 1858 \times 245.2=43.63 \times 1460 \times 200 \\
m m_{-} o i l^{\prime}=27.96416712 \mathrm{~kg} / \mathrm{s}
\end{gathered}
$$

Step 8. Calculation of number of collectors, and aperture area (solar field) required of one hour thermal storage

The total length of the additional system is found by equation (40). Equation (42) yields the result.

$m_{-}$oil $\times$Cp_oil $\times \Delta T \_o i l=$ $h \_2 \times\left(\pi \times D \times L_{-}\right.$additional $) \times\left(T_{-} p-\left(T_{-} i+T_{-} e\right) / 2\right)$

$27.964 \times 1858 \times 245.2=40.555 \times(3.14 \times 0.07 \times$

L_additional $) \times(470.4795-(12+257.2) / 2)$

$$
\text { L_additional }=4253.019951 \mathrm{~m}
$$

The number of additional collectors is writing as; \# of additional collectors $=L \_$additional $/ L_{-}$collector

$4253.019951 / 99=42.95879749 \cong 43$ Collectors $(44)$

Step 9. Calculation of number of collectors and aperture area (solar field) required with one hour thermal storage

The number of total collectors equal to the summation of the number of collectors in the system without thermal storage and the number of additional collectors needed.

$\#$ of total collectors $=$ \# of collectors + \# of additional collectors (45)

$$
182+43=225 \text { Collectors }
$$

The additional aperture area is discussed in equations (47) and (48);

Total additional aperture area $=$ \# of additional collectors $\times$ A_ap

$$
225 \times 557.37=125408.25 \mathrm{~m}^{2}
$$

Step 10. Mass flow rates with one hour thermal storage 
The mass flow rate of the oil ( $\left.\mathrm{m}_{-}{ }^{\circ} \mathrm{oil}^{\prime \prime}\right)$ is found by following formula.

$$
\mathrm{m}^{\cdot} \text { _oil }{ }^{\prime \prime} \times \text { Cp_oil } \times \Delta \mathrm{T} \text { _oil }=
$$
h_2 $\times(\pi \times D \times$ L_collector $\times \#$ of total collectors $)\left(T_{-}\right.$p -

$$
\left.\left(T_{-} i+T_{-} e\right) / 2\right)
$$

$$
\text { m_oil" } \times 1858 \times 245.2=40.555 \times(3.14 \times 0.07 \times 99 \times
$$$$
225) \times(470.4795-(12+257.2) / 2)
$$

$$
\mathrm{m}_{-} \text {oil }^{\prime \prime}=146.4610629 \mathrm{~kg} / \mathrm{s}
$$

This equality gives the mass flow rate of the molten salt. This molten salt used for one hour.

$$
\begin{aligned}
& \mathrm{m}^{\cdot} \text { _oil }{ }^{\prime \prime} \times \mathrm{Cp} \text { _oil } \times \Delta \mathrm{T} \text { _oil }=\mathrm{m}^{\cdot} \_\mathrm{ms}^{\prime} \times \mathrm{Cp} \_\mathrm{ms} \times \Delta \mathrm{T} \_\mathrm{ms}(52) \\
& 146.4610629 \times 1858 \times 245.2=\mathrm{m}^{\circ} \mathrm{ms}^{\prime} \times 1460 \times 200
\end{aligned}
$$

$$
m_{-} m^{\prime} s^{\prime}=228.5101554 \mathrm{~kg} / \mathrm{s}
$$

Step 11. The total mass of molten salt required with one hour thermal storage

The total mass of molten salt in the system is found by equation (56) and represented in Appendix B, figure 14.

$$
\begin{gathered}
m \_m s=m_{-} \_m s^{\prime} \times 3600 \\
m \_m s=228.5101554 \times 3600=833636.5594 \mathrm{~kg}=
\end{gathered}
$$$$
822.636 \text { tons }
$$

Step 12. Cost of a Collector

The collector cost is calculated by purchasing price of mirrored stainless steel. The mirrored stainless steel, used as a reflector is $0.9 \mathrm{~mm}$ thick. Related $\mathrm{m}^{2}$ price is obtained as $\$ 206.25$ [12] and it is multiplied by the total aperture area. Results are shown in equation (57). Cost of collectors for different hours of molten salt is shown in Appendix B.

$$
206.25 \$ / m^{2} \times 101441.34 m^{2}=\$ 20922276.38
$$

Step 13. Cost of Heat Transfer Fluid

Heat transfer fluid cost for zero hour molten salt storage is calculated by multiplication of the tons needed with the unit cost. Result is shown in equation (58).

74.97 tons $\times 1000 \mathrm{~kg} /$ tons $\times 3.96 \$ / \mathrm{kg}=\$ 296881.2$

Step 14. Cost of Molten Salt Inventory

Solar salt is used as molten salt. It has a $\mathrm{kg}$ cost of $\$ 0.49$. Total inventory is multiplied by the $\mathrm{kg}$ cost. Result in equation (59) yields the amount of money spent in molten salt for one hour storage and represented in monetary terms in Appendix B, Figure 14.

822.64 tons $\times 1000 \mathrm{~kg} /$ tons $\times 0.49 \$ / \mathrm{kg}=\$ 403093.6$

Step 15. Cost of Storage Tanks

The density of solar salt is known as $1899 \mathrm{~kg} / \mathrm{m}^{3}$.
Tonnage of molten salt in the inventory is divided into the density of solar salt. The new value obtained is the volume of molten salt. The next step is deciding the size of the tank. It is taken as little larger than the volume of molten salt itself. According to the volume found for the tank, approximations are done and the final results of the costs related storage tanks are discussed in figure 17 in Appendix B.

Furthermore, $10 \mathrm{MW}$ steam turbine and sun-tracking system cost is applied to the total cost. It is estimated that $15 \%$ of the total cost belongs to the tracking system. Their costs are applied to the total project cost. Cost of heat exchangers, salt pumps, project engineering and construction are not included to the estimation. Total project cost is discussed in figure 18 in Appendix B.

Step 16. Electricity Generation, Confidence Level NPV Analysis

To find the net electricity generation, similar approach should be applied as PV analysis. All calculations shown in examples are the results of zero and one hour energy storage. Others are calculated accordingly. In order to find the total GWh (Giga-watt-hours) that $10 \mathrm{MW}$ steam turbine generates electricity; yearly $\mathrm{kJ}$ (kilojoule) production of a steam turbine should be calculated.

$$
\begin{gathered}
10 \mathrm{MW}=10000 \mathrm{~kW}=10000 \mathrm{~kJ} / \mathrm{s} \\
10000 \mathrm{~kJ} / \mathrm{s} \times 3600 \mathrm{~s} / \mathrm{h} \times(7.2+0) \mathrm{h} / \mathrm{d} \times 365 \mathrm{~d} / \mathrm{a}= \\
94608000000 \mathrm{~kJ} / \mathrm{a}
\end{gathered}
$$

Annual $\mathrm{kWh}$ generation of the steam turbine can be calculated by transforming the $\mathrm{kJ}$ to $\mathrm{kWh}$. It is known that $1000 \mathrm{~kJ}$ are equivalent to $0.28 \mathrm{kWh}$.

$$
\begin{array}{r}
94608000000 \mathrm{~kJ} / a \times 0.28 \mathrm{kWh} \times 1 / 1000 \mathrm{~kJ}= \\
26490240 \mathrm{kWh} / \mathrm{a}
\end{array}
$$

The confidence level is selected as $90 \%$ as it was selected in the PV investment analysis. The net electricity generated is found as equation (63).

$$
\begin{array}{r}
26490240 \mathrm{kWh} / \mathrm{a} \times 0.90 \times 1 / 1000000 \mathrm{GWh} / \mathrm{kWh} \\
=23.841216 \mathrm{GWh} / \mathrm{a}
\end{array}
$$

Annual expected sales revenue, net present value and return on investment are calculated by the same approach of $\mathrm{PV}$ investment analysis. Operating and maintenance cost is determined by linear reduction of the cost existing on another study. It is shown detailed in figure 19 in appendix B. [13]

\section{Results and Discussion}

In the present study, engineering and economic feasibility of solar PV plants and solar parabolic trough plants are assessed. No major technical barriers were found to realize this concept. The construction location is selected as Konya, Turkey because the sunshine duration is at the country's average. However, solar irradiation is above than Turkey's annual average. Moreover, land costs are not high when it is 
compared to the project's expected annual sales revenue. All positive attributes make Konya a decent location to generate electricity by solar power.

According to the results obtained in the PV investment analysis, decision maker should consider the reliability of the module, installation costs, annual revenue and brand solidity.

On the other hand, in the parabolic trough study, it is seen that there is no large commercial availability of the materials used in the plants. Such systems require advanced engineering when it is compared to the PV plants. Thus, the calculations should be considered wisely based upon the needs of the industry.

In addition to this, molten salt technology requires high involvement to the project. Energy obtained by this technology, assists the system in order to increase the capacity factor. Thus, the system generates more electricity and increased profit. This means that the system is spending less money than it is earning by molten salt technology. However, this requires high investment cost and financial risk. These two concepts should to be taken into account by decision maker who wish to invest in this technology.

Although, parabolic trough plant yields higher income and higher NPV results, PV plants seems more reliable and less risky. In other words, PV structures are tested and used for many years. This makes the product more reliable.

It would be fair to say that neither there is enough attention to Turkey's solar energy potential nor the world's. On the other hand, it is expected to witness the improvement in the upcoming years.

Finally, all things considered, it seems that investing in both plant types are feasible in some regions of Turkey. However, as it is indicated in figures 9, 10, and 17 of Appendix, investment may not be profitable depending on the solar insolation of the location. Thus, this article suggests strategies to follow for investing in solar power plants with different solar insolation properties such as; total solar radiation, irradiance, direct radiation, and sunshine duration.

\section{Appendix A}

Step 1. Number of panels and solar field required

\begin{tabular}{|c|c|c|c|c|c|}
\hline Brand & Model & Watt & Surface Area $\left(\mathbf{m}^{\wedge} \mathbf{2}\right)$ & Solar Field $\left(\mathbf{m}^{\wedge} \mathbf{2}\right)$ & Number of Panels Required \\
\hline Astro Energy & CHSM 661OP-245 & 245 & 1.642 & 67021.51 & 40817 \\
\hline Astro Energy & CHSM 6610P-250 & 250 & 1.642 & 65680.00 & 40000 \\
\hline Astro Energy & CHSM 6612-285 & 285 & 1.994 & 68211.07 & 35088 \\
\hline Eoplly & EP125M/72-190 & 190 & 1.276 & 67158.43 & 52632 \\
\hline ET Solar & ET-P67230OWB & 300 & 1.94 & 64667.96 & 33334 \\
\hline ET Solar & ET-P660245B & 245 & 1.627 & 66409.26 & 40817 \\
\hline Helios Solar & 6 T 250 & 250 & 1.664 & 66560.00 & 40000 \\
\hline Kyocera & KD140GX-LFBS & 140 & 1.0021 & 71579.00 & 71429 \\
\hline Kyocera & KD140SX-UFBS & 140 & 1.0021 & 71579.00 & 71429 \\
\hline Kyocera & KD240GX-LPB & 240 & 1.645 & 68542.22 & 41667 \\
\hline LG & Mono X LG250S1C-G2 & 250 & 1.609 & 64360.00 & 40000 \\
\hline Sanyo & Sanyo HIT-N220A01 & 220 & 1.26 & 57273.30 & 45455 \\
\hline Sanyo & Sanyo HIT-N225A01 & 225 & 1.26 & 56000.70 & 44445 \\
\hline Sharp & Sharp ND-240aCJ & 240 & 1.629 & 67875.54 & 41667 \\
\hline Trina Solar & Trina 185 TSM-DA01 & 185 & 1.279 & 69136.35 & 54055 \\
\hline Trina Solar & Trina 230, TSM-PA05 & 230 & 1.613 & 70131.63 & 43479 \\
\hline
\end{tabular}

Figure 1. Number of Panels and Solar Field Required
Step 2. Total panel cost estimation

\begin{tabular}{|c|c|c|c|c|c|}
\hline Brand & Model & Solar Field $\left(\mathbf{m}^{\wedge} \mathbf{2}\right)$ & Number of Panels Required & Price (\$) & Total Panel Cost (in 1000 \$) \\
\hline Astro Energy & CHSM 6610P-245 & 67021.51 & 40817 & 258 & 10531 \\
\hline Astro Energy & CHSM 6610P-250 & 65680.00 & 40000 & 265 & 10600 \\
\hline Astro Energy & CHSM 6612-285 & 68211.07 & 35088 & 370 & 12983 \\
\hline Eoplly & EP125M/72-190 & 67158.43 & 52632 & 233 & 12263 \\
\hline ET Solar & ET-P672300WB & 64667.96 & 33334 & 295 & 9834 \\
\hline ET Solar & ET-P660245B & 66409.26 & 40817 & 248 & 10123 \\
\hline Helios Solar & $6 \mathrm{~T} 250$ & 66560.00 & 40000 & 310 & 12400 \\
\hline Kyocera & KD140GX-LFBS & 71579.00 & 71429 & 295 & 21072 \\
\hline Kyocera & KD140SX-UFBS & 71579.00 & 71429 & 300 & 21429 \\
\hline Kyocera & KD240GX-LPB & 68542.22 & 41667 & 433 & 18042 \\
\hline LG & Mono X LG250S1C-G2 & 64360.00 & 40000 & 410 & 16400 \\
\hline Sanyo & Sanyo HIT-N220A01 & 57273.30 & 45455 & 715 & 32500 \\
\hline Sanyo & Sanyo HIT-N225A01 & 56000.70 & 44445 & 690 & 30667 \\
\hline Sharp & Sharp ND-240QCJ & 67875.54 & 41667 & 330 & 13750 \\
\hline Trina Solar & Trina 185 TSM-DA01 & 69136.35 & 54055 & 333 & 18000 \\
\hline Trina Solar & Trina 230, TSM-PAO5 & 70131.63 & 43479 & 360 & 15652 \\
\hline
\end{tabular}

Figure 2. Total Panel Cost Estimation

Step 3. Calculation of positive and negative tolerance levels of the photovoltaic module

\begin{tabular}{|c|c|c|c|c|c|c|}
\hline Brand & Model & Watt & Tolerance & (-) Tolerance & (-) Tolerance Level (W) & (+) Tolerance Level (W) \\
\hline Astro Energy & CHSM 6610P-245 & 245 & $3 \%$ & $0 \%$ & 245 & 252.35 \\
\hline Astro Energy & CHSM 6610P-250 & 250 & $3 \%$ & $0 \%$ & 250 & 257.5 \\
\hline Astro Energy & CHSM 6612-285 & 285 & $3 \%$ & $0 \%$ & 285 & 293.55 \\
\hline Eoplly & EP125M/72-190 & 190 & $3 \%$ & $3 \%$ & 184.3 & 195.7 \\
\hline ET Solar & ET-P672300WB & 300 & $3 \%$ & $1 \%$ & 297 & 309 \\
\hline ET Solar & ET-P660245B & 245 & $2 \%$ & $0 \%$ & 245 & 249.9 \\
\hline Helios Solar & $6 \mathrm{~T} 250$ & 250 & $3 \%$ & $0 \%$ & 250 & 257.5 \\
\hline Kyocera & KD140GX-LFBS & 140 & $0 \%$ & $5 \%$ & 133 & 140 \\
\hline Kyocera & KD140SX-UFBS & 140 & $0 \%$ & $5 \%$ & 133 & 140 \\
\hline Kyocera & KD240GX-LPB & 240 & $5 \%$ & $3 \%$ & 232.8 & 252 \\
\hline LG & Mono X LG250S1C-G2 & 250 & $0 \%$ & $3 \%$ & 242.5 & 250 \\
\hline Sanyo & Sanyo HIT-N220A01 & 220 & $10 \%$ & $0 \%$ & 220 & 242 \\
\hline Sanyo & Sanyo HIT-N225A01 & 225 & $10 \%$ & $0 \%$ & 225 & 247.5 \\
\hline Sharp & Sharp ND-240QCJ & 240 & $0 \%$ & $5 \%$ & 228 & 240 \\
\hline Trina Solar & Trina 185 TSM-DA01 & 185 & $3 \%$ & $0 \%$ & 185 & 190.55 \\
\hline Trina Solar & Trina 230, TSM-PAO5 & 230 & $3 \%$ & $0 \%$ & 230 & 236.9 \\
\hline
\end{tabular}

Figure 3. Tolerance Levels

Step 4. Estimated yearly electricity generation

\begin{tabular}{|c|c|c|c|c|c|c|c|c|}
\hline Brand & Model & (t) Tolerance & -) Tolerance & (-) Tolerance Level (W) & ) (t) Tolerance Level (W) & Neg MWH/year & Pos MWH/yea & Avg MWH/veat \\
\hline Astro Energy & CHSM 66100-245 & $3 \%$ & $0 \%$ & 245.0 & 252.4 & 26280.4 & 27068.8 & 26674.6 \\
\hline Astro Energy & CHSM 6610P-250 & $3 \%$ & $0 \%$ & 250.0 & 257.5 & 26280.0 & 27068.4 & 26674.2 \\
\hline Astro Energy & CHSM 6612-285 & $3 \%$ & $0 \%$ & 285.0 & 293.6 & 26280.2 & 27068.6 & 26674.4 \\
\hline Eoplly & EP125M/72-190 & $3 \%$ & $3 \%$ & 184.3 & 195.7 & 25491.8 & 27068.6 & 26280.2 \\
\hline ET Solar & ET.P672300WB & $3 \%$ & $1 \%$ & 297.0 & 309.0 & 26017.7 & 27068.9 & 26543.3 \\
\hline ET Solar & ET-P660245B & $2 \%$ & $0 \%$ & 245.0 & 249.9 & 26280.4 & 26806.0 & 26543.2 \\
\hline Helios Solar & $6 \mathrm{~T} 250$ & $3 \%$ & $0 \%$ & 250.0 & 257.5 & 26280.0 & 27068.4 & 26674.2 \\
\hline Kyocera & KD140GX-LFBS & $0 \%$ & $5 \%$ & 133.0 & 140.0 & 24966.1 & 26280.2 & 25623.2 \\
\hline Kyocera & KD140SX-UFBS & $0 \%$ & $5 \%$ & 133.0 & 140.0 & 24966.1 & 26280.2 & 25623.2 \\
\hline Kyocera & KD2406X-LPB & $5 \%$ & $3 \%$ & 232.8 & 252.0 & 25491.8 & 27594.2 & 26543.0 \\
\hline LG & Mono X LG25051C-G2 & $0 \%$ & $3 \%$ & 242.5 & 250.0 & 25491.6 & 26280.0 & 25885.8 \\
\hline Sanyo & Sanyo HIT-N220A01 & $10 \%$ & $0 \%$ & 220.0 & 242.0 & 26280.3 & 28908.3 & 27594.3 \\
\hline Sanyo & Sanyo HIT-N225A01 & $10 \%$ & $0 \%$ & 225.0 & 247.5 & 26280.3 & 28908.4 & 27594.3 \\
\hline Sharp & Sharp ND-2400CJ & $0 \%$ & $5 \%$ & 228.0 & 240.0 & 24966.2 & 26280.2 & 25623.2 \\
\hline Trina Solar & Trina 185 TSM-DA01 & $3 \%$ & $0 \%$ & 185.0 & 190.6 & 26280.5 & 27068.9 & 26674.7 \\
\hline Trina Solar & Trina 230, TSM-PAOS & $3 \%$ & $0 \%$ & 230.0 & 236.9 & 26280.4 & 27068.9 & 26674.7 \\
\hline
\end{tabular}

Figure 4. Average Tolerance Level

Step 5, Step 6, Step 7, Step 8. DC cable, Inverter integration, Transformer and local network connection, String monitor

\begin{tabular}{|c|c|c|c|c|c|c|c|}
\hline Brand & Model & Land (in\$1000) & Inverter (in \$1000) & Transformer (in \$1000) & Power Line (in \$1000) & String Monitor (in \$1000) & ) DC Cable (in \$1000) \\
\hline Astro Energy & CHSM 6610 P-245 & 247.59 & $1,969.93$ & 38.93 & 1,111 & $5,448.64$ & 615.5 \\
\hline Astro Energy & CHSM 66110 - 250 & 247.59 & 1,876.12 & 38.93 & 1,111 & $5,339.73$ & 603.2 \\
\hline Astro Energy & CHSM6612-285 & 247.59 & 1,688.51 & 38.93 & 1,111 & 4,683.08 & 529.1 \\
\hline Eoolly & EP125M/72-190 & 247.59 & $2,532.76$ & 38.93 & 1,111 & $7,024.62$ & 793.7 .7$. \\
\hline ET Solar & ET-P67230OWB & 247.59 & $1,594.70$ & 38.93 & 1,111 & 4,449.24 & 502.7 \\
\hline ET Solar & ET.P660225B & 247.59 & 1,969.93 & 38.93 & 1,111 & $5,448.64$ & 615.5 \\
\hline Helios Solar & 6 Т 250 & 247.59 & 1,876.12 & 38.93 & 1,111 & $5,339.73$ & \\
\hline Kyocera & KD240GX-LPB & 247.59 & 1,969.93 & 38.93 & 1,111 & $5,563.96$ & \\
\hline Kyocera & KD140GX-LFBS & 247.59 & $3,377.02$ & 38.93 & 1,111 & $9,535.93$ & $1,077.1$ \\
\hline Kyocera & KD140SX-UFBS & 247.59 & $3,377.02$ & 38.93 & 1,111 & $9,535.93$ & $1,077.1$ \\
\hline LG & Mono X L6250S1C-G2 & 247.59 & 1,876.12 & 38.93 & 1,111 & $5,339.73$ & 603.2. \\
\hline Sanyo & Sanyo HIT-N225A01 & 247.59 & $2,157.54$ & 38.93 & 1,111 & $5,932.33$ & 670.2 \\
\hline Sanyo & Sanyo HIT-N220A01 & 247.59 & 2,157.54 & 38.93 & 1,111 & $6,066.86$ & 685.5 \\
\hline Sharp & Sharp ND-2400CJ & 247.59 & 1,969.93 & 38.93 & 1,111 & $5,563.96$ & 628.3 \\
\hline Trina Solar & Trina 230, TSM-PA05 & 247.59 & $2,063.73$ & 38.93 & 1,111 & $5,804.20$ & 655. \\
\hline Trina Solar & Trina 185 TSM-DA01 & 24759 & 262657 & 38.93 & 11111 & 721681 & 1 \\
\hline
\end{tabular}

Figure 5. DC cable, Inverter, Transformer, Power Line, Monitoring Costs

Step 9. Efficiency parameters, efficiency applied 
electricity generation and confidence level

\begin{tabular}{|c|c|c|c|c|c|c|c|c|c|}
\hline Brand & Model & Module Eff' & * Inverter Eff' & "Cable Efft" T & Transformer Eff* & * Power line & Efff"Coef"* & * Confidence Level & Net MWH Generation \\
\hline Astro Energy & CHSM 6610P-245 & 0.8 & 0.92 & 0.99 & 0.99 & 0.94 & 0.678 & 0.9 & 16278.60 \\
\hline Astro Energy & CHSM 6610P-250 & 0.8 & 0.92 & 0.99 & 0.99 & 0.94 & 0.678 & 0.9 & 16678.33 \\
\hline Astro Energy & CHSM $6612-285$ & 0.8 & 0.92 & 0.99 & 0.99 & 0.94 & 0.678 & 0.9 & 16278.46 \\
\hline Eoplly & EP125M/72-190 & 0.8 & 0.92 & 0.99 & 0.99 & 0.94 & 0.678 & 0.9 & 16037.90 \\
\hline ET Solar & E.-P672300WB & 0.892 & 0.92 & 0.99 & 0.99 & 0.94 & 0.756 & 0.9 & 18061.29 \\
\hline ET Solar & ET-P660245B & 0.892 & 0.92 & 0.99 & 0.99 & 0.94 & 0.756 & 0.9 & 18061.23 \\
\hline Helios Solar & 61250 & 0.8 & 0.92 & 0.99 & 0.99 & 0.94 & 0.678 & 0.9 & 16278.33 \\
\hline Kyocera & KD140GX-LFBS & 0.858 & 0.92 & 0.99 & 0.99 & 0.94 & 0.727 & 0.9 & 16770.59 \\
\hline kyocera & KD190SX-UFBS & 0.858 & 0.92 & 0.99 & 0.99 & 0.94 & 0.727 & 0.9 & 16770.59 \\
\hline Kyocera & KD2240GX-LPB & 0.858 & 0.92 & 0.99 & 0.99 & 0.94 & 0.727 & 0.9 & 17372.65 \\
\hline LG & Mono X LG25051C-G2 & 0.886 & 0.92 & 0.99 & 0.99 & 0.94 & 0.751 & 0.9 & 17495.40 \\
\hline Sanyo & Sanyo HIT-N220A01 & 0.8 & 0.92 & 0.99 & 0.99 & 0.94 & 0.678 & 0.9 & 16839.82 \\
\hline Sanyo & Sanyo HTT-N225AO1 & 0.8 & 0.92 & 0.99 & 0.99 & 0.94 & 0.678 & 0.9 & 16839.87 \\
\hline Sharp & Sharp ND-2400,CJ & 0.8 & 0.92 & 0.99 & 0.99 & 0.94 & 0.678 & 0.9 & 15636.95 \\
\hline Trina Solar & Trina 185 TSM-DA01 & 0.8 & 0.92 & 0.99 & 0.99 & 0.94 & 0.678 & 0.9 & 16278.62 \\
\hline Trina Solar & Trina 230, TSM-PAOS & 0.8 & 0.92 & 0.99 & 0.99 & 0.94 & 0.678 & 0.9 & 16278.61 \\
\hline
\end{tabular}

Figure 6. Efficiency Coefficient and Net Electricity Generation with Confidence Level

Step 10. Expected annual sales revenue and Net Present Value approach

\begin{tabular}{|c|c|c|c|c|c|c|c|c|c|}
\hline Brand & Model & Totat Panel (in 5 S1000) & land (instion) & veter $[$ in 5 S100) I & 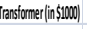 & Power line [in $51000 \mid$ st & 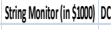 & cable (instion) To & 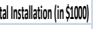 \\
\hline Astrobererg & 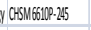 & 10,531 & 24.59 & 1,999.93 & 3293 & 1,111 & $5,546.64$ & 615.5 & 19,96239 \\
\hline Astrohenerg & 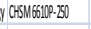 & 10,600 & 24.59 & 1.866 .12 & 3293 & 1,111 & $5,339,13$ & 603.2 & 1981657 \\
\hline Astrobergers & 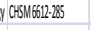 & 12,2983 & 24.59 & 1,68251 & 3293 & 1,111 & $4,683: 18$ & 59.1 & 21,20079 \\
\hline Eoplly & EP1213N/72:10 & 12,263 & 24.59 & 2,52226 & 3293 & 1,111 & $7,04,62$ & 793.7 & 24,01184 \\
\hline ETSolar & EF-F6730ONB & 98,84 & 24.59 & 1,5440 & 3293 & 1,111 & 4,49.24 & 502.7 & $17,77.67$ \\
\hline ETSolar & EPr6502458 & 10,123 & 24.59 & 1,99993 & 3293 & 1,111 & $5,496.64$ & 615.5 & 19,554.22. \\
\hline Heliossolar & 6150 & 12,400 & 24.59 & 1.866 .12 & 3293 & 1,111 & $5,399,13$ & 603.2 & $2,1,6657$ \\
\hline Kvoerer & 1024601.18B & 18,022 & 24.59 & 1,69993 & 3293 & 1,111 & 5,53396 & 6283 & 27,6055 \\
\hline Kpoera & 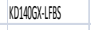 & $2,0,02$ & 24.59 & 3,371.0.2 & 3293 & 1,111 & $9,535.93$ & 1,077.1 & 3,459.17 \\
\hline Kpoerar & KOALSSXVVIPSS & 2,4,49 & 29.59 & 3,371.02 & 3293 & 1,111 & 9,53593 & 1.077.1 & 36,861321 \\
\hline 16 & 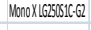 & 16,40 & 24.59 & 1.866 .2 & 3293 & 1,111 & $5,3397,13$ & 603.2 & 25,6657 \\
\hline $\operatorname{san} 0$ & 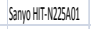 & 30,607 & 24.59 & $2,157.54$ & 3293 & 1,111 & 5,923233 & 60.2 & 40,82466 \\
\hline Sanio & Sampohr-N2ranol & 32,50 & 24.59 & 2,15:54 & 3293 & 1,111 & 6,05586 & 6055 & 42,807.70 \\
\hline Sharp & Shap ND-240C, J & 13,750 & 24.59 & $1,89.93$ & 3293 & 1,111 & $5,533.96$ & 628.3 & 23,30985 \\
\hline Trina Solat & 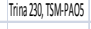 & 15,622 & 24.59 & 2,03233 & 3293 & 1,111 & 5,80420 & 655.7 & 25,57355 \\
\hline Tiña Solar & 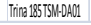 & 18,000 & 24.59 & 2,0657 & 3893 & 1,111 & 7,21681 & 815.1 & $3,0,5636$ \\
\hline
\end{tabular}

Figure 7. Total Installation Cost

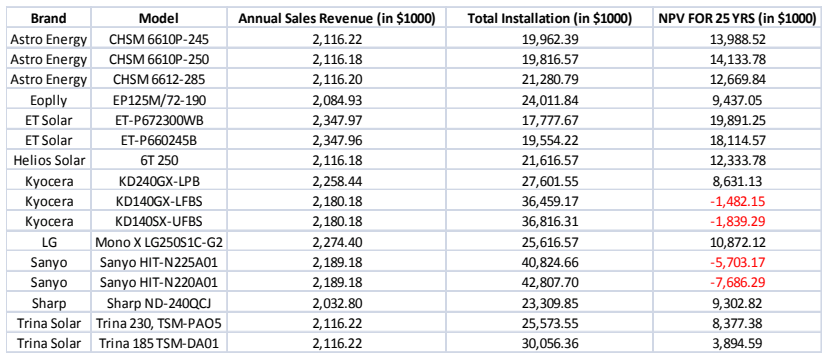

Figure 8. NPV Analysis

As table indicates, there are several positive and negative net present values exists. Thus, to have crystal clear idea about brands in this investment; model with the highest NPV of a brand is selected and further investigations applied.

First all, the main task is the identification the highest NPV yielding model. Right after its identification, all results are compared. Calculations are done according to the 7.2 hours of sunshine duration in Konya. Other cities are discussed with their different sunshine duration. New NPV calculations for other cities are done by having the same models of brands discussed in the next section.

\begin{tabular}{|c|c|c|c|c|c|c|c|c|c|}
\hline Case & ET SOLAR & ASTRO ENG & HELIOS & LG & EOPLLY & SHARP & KYOCERA & TRINA & SANYO \\
\hline Site & Konya & Konya & Konya & Konya & Konya & Konya & Konya & Konya & Konya \\
\hline Sun Duration (h) & 7.2 & 7.2 & 7.2 & 7.2 & 7.2 & 7.2 & 7.2 & 7.2 & 7.2 \\
\hline Nominal Power (MW) & 10 & 10 & 10 & 10 & 10 & 10 & 10 & 10 & 10 \\
\hline PV Required & 33334 & 40000 & 40000 & 40000 & 52632 & 41667 & 41667 & 43479 & 44445 \\
\hline Peak Power (W) & 300 & 250 & 250 & 250 & 190 & 240 & 240 & 230 & 225 \\
\hline Avg Tolerance Level (W) & 303.00 & 253.75 & 253.75 & 246.25 & 190 & 234 & 242.4 & 233.45 & 236.25 \\
\hline Power Block Gross Efficiency & 0.89 & 0.80 & 0.80 & 0.89 & 0.80 & 0.80 & 0.86 & 0.80 & 0.80 \\
\hline \multicolumn{10}{|l|}{ Plant Performance } \\
\hline Operating Scenario & Solar Only & Solar Only & Solar Only & Solar Only & Solar Only & Solar Only & Solar Only & Solar Only & Solar Only \\
\hline Produced (GWh/a) & 23.68 & 21.34 & 21.34 & 22.93 & 21.02 & 20.50 & 22.77 & 21.34 & 22.08 \\
\hline Inverter Efficiency & 0.92 & 0.92 & 0.92 & 0.92 & 0.92 & 0.92 & 0.92 & 0.92 & 0.92 \\
\hline Transformer Efficiency & 0.99 & 0.99 & 0.99 & 0.99 & 0.99 & 0.99 & 0.99 & 0.99 & 0.99 \\
\hline Cable Efficiency & 0.99 & 0.99 & 0.99 & 0.99 & 0.99 & 0.99 & 0.99 & 0.99 & 0.99 \\
\hline Gross (GWh/a) & 21.35 & 19.24 & 19.24 & 20.68 & 18.96 & 18.48 & 20.54 & 19.24 & 19.91 \\
\hline Power Line Efficiency & 0.94 & 0.94 & 0.94 & 0.94 & 0.94 & 0.94 & 0.94 & 0.94 & 0.94 \\
\hline Total Fuel $\left(10^{\wedge} 6 \mathrm{~m}^{\wedge} 3 / \mathrm{a}\right)$ & 0 & 0 & 0 & 0 & 0 & 0 & 0 & 0 & 0 \\
\hline Capacity Factor & $21 \%$ & $19 \%$ & $19 \%$ & $20 \%$ & $18 \%$ & $18 \%$ & $20 \%$ & $19 \%$ & $19 \%$ \\
\hline Confidence Level & $90 \%$ & $90 \%$ & $90 \%$ & $90 \%$ & $90 \%$ & $90 \%$ & $90 \%$ & $90 \%$ & $90 \%$ \\
\hline Net Electric (GWh/a) & 18.06 & 16.28 & 16.28 & 17.50 & 16.04 & 15.64 & 17.37 & 16.28 & 16.84 \\
\hline \multicolumn{10}{|l|}{ Economy } \\
\hline Total Project Cost (in 1000 USD) & 17778 & 19817 & 21617 & 25617 & 24012 & 23310 & 27602 & 25574 & 40825 \\
\hline Exp Annual Sales Rev (in 1000 USD) & 2348 & 2116 & 2116 & 2274 & 2085 & 2033 & 2258 & 2116 & 2189 \\
\hline Return on Investment (in years) & 7.57 & 9.36 & 10.21 & 11.26 & 11.52 & 11.47 & 12.22 & 12.08 & 18.65 \\
\hline NPV for 25 years (in 1000 USD) & 19891 & 14134 & 12334 & 10872 & 9437 & 9303 & 8631 & 8377 & -5703 \\
\hline
\end{tabular}




\begin{tabular}{|l|r|r|r|r|r|r|r|r|r|r|}
\hline Cities & Sunshine Duration & ET SOLAR & ASTRO ENG & HELIOS & LG & EOPLLY & SHARP & KYOCERA & TRINA & SANYO \\
\hline Konya & 7.2 & 24077 & 17906 & 16106 & 14926 & 13154 & 12926 & 12657 & 12150 & -1801 \\
\hline Antalya & 8.425 & 31198 & 24324 & 22524 & 21824 & 19477 & 19092 & 19507 & 18568 & 4839 \\
\hline Izmir & 7.833 & 27756 & 21222 & 19422 & 18491 & 16421 & 16112 & 16196 & 15466 & 1630 \\
\hline Edirne & 6.05 & 17392 & 11881 & 10081 & 8451 & 7217 & 7139 & 6227 & 6124 & -8034 \\
\hline Sinop & 5.417 & 13712 & 8564 & 6764 & 4886 & 3950 & 3953 & 2687 & 2808 & -11465 \\
\hline Trabzon & 4.483 & 8282 & 3671 & 1871 & -373 & -871 & -748 & -2535 & -2086 & -16527 \\
\hline Agri & 6.158 & 18019 & 12447 & 10647 & 9059 & 7775 & 7682 & 6831 & 6690 & -7448 \\
\hline Sanliurfa & 8.017 & 28826 & 22187 & 20387 & 19527 & 17371 & 17038 & 17225 & 16430 & 2627 \\
\hline
\end{tabular}

Figure 9. NPV Comparison of Brands

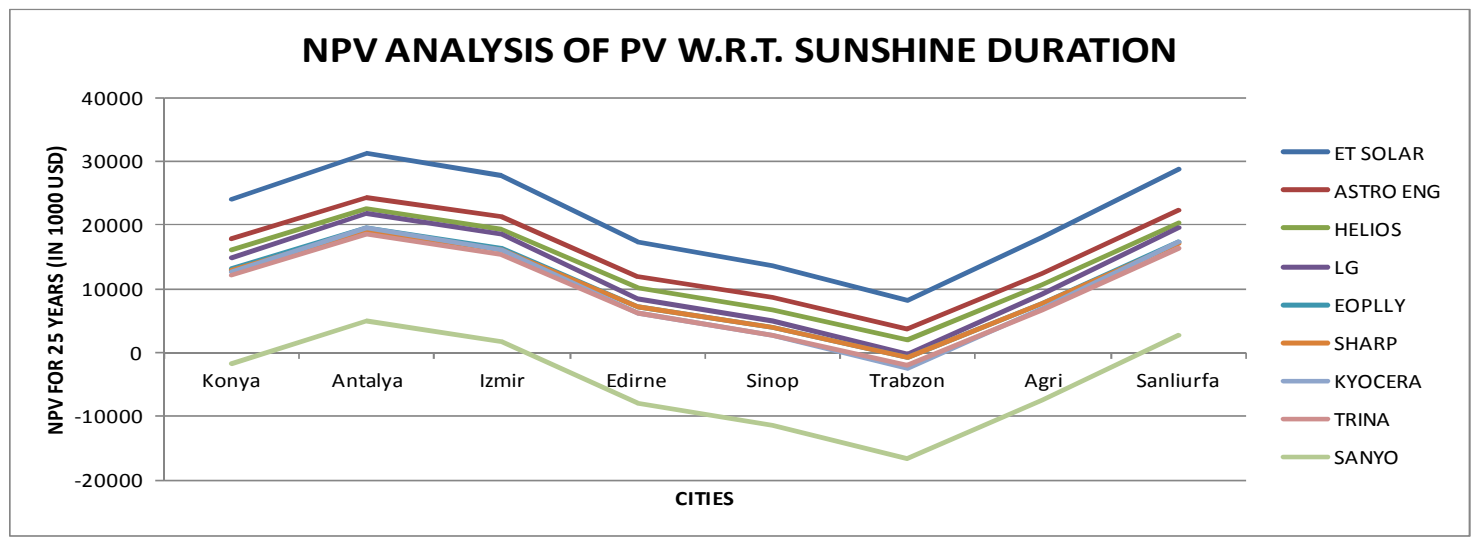

Figure 10. Comparison of Different Brands in Different Cities

\section{Appendix B}

Step 5. Calculation of number of collectors and aperture area required

\begin{tabular}{|l|r|r|r|r|r|r|}
\hline & 10 MW /0h & 10 MW /1h & 10 MW /3h & $10 \mathrm{MW} / 6 \mathrm{~h}$ & $10 \mathrm{MW} / 9 \mathrm{~h}$ \\
\hline Additional Collectors & 0 & 43 & 129 & 258 & 387 \\
\hline Total Number of Collectors & 182 & 225 & 311 & 440 & 569 \\
\hline Total Aperture Area (in $\mathrm{m}^{\wedge}$ 2) & 101441.34 & 125408.25 & 173342.07 & 245242.8 & 317143.53 \\
\hline
\end{tabular}

Figure 11. Total Collector Requirement with Different Hours of Molten Salt Storage

Step 12. Cost of a Collector

\begin{tabular}{|c|c|c|c|c|c|}
\hline & $10 \mathrm{MW} / 0 \mathrm{~h}$ & $10 \mathrm{MW} / \mathrm{hh}$ & $10 \mathrm{MW} / 3 \mathrm{~h}$ & $10 \mathrm{MW} / 6 \mathrm{~h}$ & $10 \mathrm{MW} / 9 \mathrm{~h}$ \\
\hline Additional Collectors & 0 & 43 & 129 & 258 & 387 \\
\hline Total Number of Collectors & 182 & 225 & 311 & 440 & 569 \\
\hline Total Aperture Area (in $\mathrm{m}^{\wedge} 2$ ) & 101441.34 & 125408.25 & 173342.07 & 245242.8 & 317143.53 \\
\hline Collectors (in \$1000) & 20922.28 & 25865.45 & 35751.80 & 50581.33 & 65410.85 \\
\hline
\end{tabular}

Figure 12. Cost of a Collector

Step 13. Cost of Heat Transfer Fluid

\begin{tabular}{|c|c|c|c|c|c|}
\hline & $10 \mathrm{MW} / \mathrm{Oh}$ & $10 \mathrm{MW} / \mathbf{1 h}$ & $10 \mathrm{MW} / 3 \mathrm{~h}$ & $10 \mathrm{MW} / 6 \mathrm{~h}$ & $10 \mathrm{MW} / 9 \mathrm{~h}$ \\
\hline Heat Transfer Fluid (in tons) & 74.97 & 90.92 & 122.84 & 170.71 & 218.58 \\
\hline Heat Transfer Fluid $(\$ / \mathrm{kg})$ & 3.96 & 3.96 & 3.96 & 3.96 & 3.96 \\
\hline Heat Transfer Fluid (in $\$ 1000$ ) & 296.87 & 360.06 & 486.44 & 676.01 & 865.58 \\
\hline
\end{tabular}

Figure 13. Cost of Heat Transfer Fluid

Step 14. Cost of Molten Salt Inventory

\begin{tabular}{|c|c|c|c|c|c|}
\hline & $10 \mathrm{MW} / 0 \mathrm{~h}$ & $10 \mathrm{MW} / \mathrm{hh}$ & $10 \mathrm{MW} / 3 \mathrm{~h}$ & $10 \mathrm{MW} / 6 \mathrm{~h}$ & $10 \mathrm{MW} / 9 \mathrm{~h}$ \\
\hline Molten Salt Inventory (tons) & 0 & 822.64 & 1137.07 & 1608.71 & 2080.36 \\
\hline Molten Salt Inventory $(\$ / \mathrm{kg})$ & 0 & 0.49 & 0.49 & 0.49 & 0.49 \\
\hline Molten Salt Inventory (in \$1000) & 0 & 403.09 & 557.16 & 788.27 & 1019.37 \\
\hline
\end{tabular}

Figure 14. Cost of Molten Salt Inventory
Step 15. Cost of Storage Tanks

\begin{tabular}{|c|c|c|c|c|c|}
\hline & $10 \mathrm{MW} / \mathrm{Oh} 1$ & $\mathrm{W} / \mathrm{1h}$ & $\mathrm{nW} / 3 \mathrm{~h} 1$ & $1 \mathrm{~W} / 6 \mathrm{~h}$ & MW/9h \\
\hline Molten Salt Density $\left(\mathrm{kg} / \mathrm{m}^{\wedge} 3\right)$ & 0 & 1899 & 1899 & 1899 & 1899 \\
\hline Volume of Molten Salt $\left(\mathrm{m}^{\wedge} 3\right)$ & 0 & 433 & 599 & 847 & 1096 \\
\hline Volume of Tank (m^3) & 0 & 450 & 615 & 865 & 1115 \\
\hline Storage Tanks (in \$1000) & 0 & 145.20 & 194.47 & 263.66 & 335.13 \\
\hline Tank Foundation (in \$1000) & 0 & 89.75 & 79.57 & 93.97 & 111.34 \\
\hline Tank Insulation (in \$1000) & 0 & 51.98 & 49.16 & 55.37 & 63.68 \\
\hline
\end{tabular}

Figure 15. Cost of Storage Tanks

\begin{tabular}{|c|c|c|c|c|c|}
\hline Total Project Cost & $10 \mathrm{MW} / 0 \mathrm{~h}$ & $10 \mathrm{MW} / 1 \mathrm{~h}$ & $10 \mathrm{MW} / 3 \mathrm{~h}$ & $10 \mathrm{MW} / 6 \mathrm{~h}$ & $10 \mathrm{MW} / 9 \mathrm{~h}$ \\
\hline \multicolumn{6}{|l|}{ Solar Field } \\
\hline Additional Collectors & 0 & 43 & 129 & 258 & 387 \\
\hline Total Number of Collectors & 182 & 225 & 311 & 440 & 569 \\
\hline Total Aperture Area (in $\mathrm{m}^{\wedge} 2$ ) & 101441.34 & 125408.25 & 173342.07 & 245242.8 & 317143.53 \\
\hline Collectors (in $\$ 1000$ ) & 20922.28 & 25865.45 & 35751.80 & 50581.33 & 65410.85 \\
\hline Sun- Tracking (in \$1000) & 3868.09 & 4873.33 & 6673.87 & 9380.93 & 12089.29 \\
\hline Heat Transfer Fluid (in tons) & 74.97 & 90.92 & 122.84 & 170.71 & 218.58 \\
\hline Heat Transfer Fluid (\$/kg) & 3.96 & 3.96 & 3.96 & 3.96 & 3.96 \\
\hline Heat Transfer Fluid (in \$1000) & 296.87 & 360.06 & 486.44 & 676.01 & 865.58 \\
\hline \multicolumn{6}{|l|}{ Storage System } \\
\hline Molten Salt Inventory (tons) & 0 & 822.64 & 1137.07 & 1608.71 & 2080.36 \\
\hline Molten Salt Inventory $(\$ / \mathrm{kg})$ & 0 & 0.49 & 0.49 & 0.49 & 0.49 \\
\hline Molten Salt Inventory (in \$1000) & 0 & 403.09 & 557.16 & 788.27 & 1019.37 \\
\hline Molten Salt Density $\left(\mathrm{kg} / \mathrm{m}^{\wedge} 3\right)$ & 0 & 1899 & 1899 & 1899 & 1899 \\
\hline Volume of Molten Salt $\left(\mathrm{m}^{\wedge} \mathrm{3}\right)$ & 0 & 433 & 599 & 847 & 1096 \\
\hline Volume of Tank $\left(\mathrm{m}^{\wedge} \mathrm{3}\right)$ & 0 & 450 & 615 & 865 & 1115 \\
\hline Storage Tanks (in \$1000) & 0 & 145.20 & 194.47 & 263.66 & 335.13 \\
\hline Tank Foundation (in \$1000) & 0 & 89.75 & 79.57 & 93.97 & 111.34 \\
\hline Tank Insulation (in \$1000) & 0 & 51.98 & 49.16 & 55.37 & 63.68 \\
\hline \multicolumn{6}{|l|}{ Power Plant Block } \\
\hline Steam Turbine (in $\$ 1000$ ) & 700 & 700 & 700 & 700 & 700 \\
\hline Land (in \$1000) & 251.89 & 251.89 & 251.89 & 251.89 & 251.89 \\
\hline Total Project Cost (in \$1000) & 26039 & 32741 & 44744 & 62791 & 80847 \\
\hline
\end{tabular}

Figure 16. Total Project Cost of Parabolic Trough Power Plant

Step 16. Electricity Generation, Confidence Level NPV Analysis 


\begin{tabular}{|c|c|c|c|c|c|}
\hline Case & $10 \mathrm{MW} / \mathrm{oh}$ & $10 \mathrm{MW} / \mathrm{hh}$ & $10 \mathrm{MW} / 3 \mathrm{~h}$ & $10 \mathrm{MW} / 6 \mathrm{~h}$ & $10 \mathrm{MW} / 9 \mathrm{~h}$ \\
\hline Site & Konya & Konya & Konya & Konya & Konya \\
\hline Total Solar Radiation (kWh/m^2a) & 1700 & 1700 & 1700 & 1700 & 1700 \\
\hline Irradiance $\left(\mathrm{W} / \mathrm{m}^{\wedge} 2\right)$ & 660 & 660 & 660 & 660 & 660 \\
\hline Direct Radiation $\left(\mathrm{W} / \mathrm{m}^{\wedge} 2\right)$ & 330 & 330 & 330 & 330 & 330 \\
\hline Sunshine Duration & 7.2 & 7.2 & 7.2 & 7.2 & 7.2 \\
\hline Nominal Power (MW) & 10 & 10 & 10 & 10 & 10 \\
\hline Storage size $(h)$ & 0 & 1 & 3 & 6 & \\
\hline Total Aperture Area $\left(\mathrm{m}^{\wedge} \mathrm{2}\right)$ & 101441 & 125408 & 173342 & 245243 & 317144 \\
\hline \multicolumn{6}{|l|}{ Plant Performance } \\
\hline Operating Scenario & Solar only & Solar only & Solar only & Solar only & Solar only \\
\hline Steam Turbine Production (kJ/a) & 94608000000 & 107748000000 & 134028000000 & 173448000000 & 212868000000 \\
\hline Steam Turbine, Net (kWh/a) & 26490240 & 30169440 & 37527840 & 48565440 & 59603040 \\
\hline Total Fuel $\left(10^{\wedge} 6 \mathrm{~m}^{\wedge} 3 / \mathrm{a}\right)$ & 0 & 0 & 0 & 0 & \\
\hline Capacity Factor & $27 \%$ & $31 \%$ & $39 \%$ & $50 \%$ & $61 \%$ \\
\hline Confidence Level & $90 \%$ & $90 \%$ & $90 \%$ & $90 \%$ & $90 \%$ \\
\hline Net Electric (GWh/a) & 23.84 & 27.15 & 33.78 & 43.71 & 53.64 \\
\hline \multicolumn{6}{|l|}{ Economy } \\
\hline Total Project Cost (in 1000 USD) & 26039 & 32741 & 44744 & 62791 & 80847 \\
\hline Annual Expected Sales Rev (in 1000 USD) & 3099 & 3530 & 4391 & 5682 & 6974 \\
\hline Annual O\&M Cost (in 1000 USD) & 703 & 730 & 769 & 836 & 900 \\
\hline Return on Investment (in years) & 15.5 & 16.5 & 17.2 & 17.8 & 18.1 \\
\hline NPV for 25 years (in 1000 USD) & 12409.3 & 12171.0 & 13366.6 & 14953.2 & 16598.6 \\
\hline
\end{tabular}

Figure 17. NPV Analysis of Parabolic Trough Power Plant

\section{References}

[1] Deloitte, Sunny Days at Renewable Energy, 2012, Available at

http://www.deloitte.com/assets/Dcom-Turkey/Local\%20Ass ets/Documents/turkey_tr_enerji_yenilenebilirdegunesligunle r_010812.pdf (from Turkish)

[2] Construction Site, March 2013, Available at http://www.milliemlak.gov.tr

[3] Photovoltaic Power Plant Electricity Generation Scheme, 2006, Available http://holbert.faculty.asu.edu/eee463/SOLAR.HTML

[4] DC Cable Information, March 2013, Available at http://www.topcable.com/es/tipos-de-cable/Cables-fotovolta icos/

[5] DC Cable Price Information, March 2013, Available at $\mathrm{http}$ //store.proinso.net/europe/cavi/top-cable-topsolar-pv-zz
-f-as-1x10-p_185.html?osCsid=0jveknid3qj5in3 lughgog2 1 31

[6] Inverter Information, March 2013, Available at http://store.proinso.net/europe/sma/sunny-central-c_32_70_ 38.html

[7] Transformer Information, March 2013, Available at http://store.proinso.net/europe/sunny-central/sma-sunny-cen tral-tsc-500sc-de-p_514.html

[8] String Monitor Price Information, March 2013, Available at $\mathrm{http} / / /$ store.proinso.net/europe/quadri-di-campo/sma-sunny-s tring-monitor-16-21-p_481.html

[9] PV Module Information, March 2013, Available at http://www.wholesalesolar.com/

[10] Solar Millenium Animation, March 2013, Available at http://www.solarmillennium-invest.de/cms/upload/Flash/and asol_blue_engl.swf

[11] Tadahmun Ahmed Yassen, Experimental and Theoretical Study of a Parabolic Trough Solar Collector, Anbar Journal for Engineering Sciences AJES-2012, Vol.5, No.1

[12] Mirrored Stainless Steel Price Information, March 2013, Available at http://csmirrors.co.uk/stainless-steel-mirrors/

[13] Ulf Herrmann, Bruce Kelly, Henry Price, Two-Tank Molten Salt Storage for Parabolic Trough Solar Power Plants, Elsevier Science Direct Energy 29 (2004) 883-893

[14] Rankine Cycle, November 2013, Available at http://www.thermopedia.com/content/1072/

[15] Definition of Enthalpy, November 2013, Available at http:/hyperphysics.phy-astr.gsu.edu/hbase/thermo/firlaw.ht $\mathrm{ml}$

[16] Mollier Diagram, November 2013, Available at http://www.engineeringtoolbox.com/mollier-diagram-waterd_308.html 